\title{
Duplik: Vedrørende anmeldelse af Arabisk Medicin af Irmeli Perho
}

\author{
Af ph.d. Philippe Provençal
}

Vedrørende Irmeli Perhos anmeldelse af bogen Arabisk Medicin som står s. 109-110 i

Tidsskrift for Islamforskning nr. 3, 2008 vil jeg gerne komme med følgende kommentarer. Arabisk Medicin er skrevet af undertegnede.

Perho bruger hele anmeldelsen, bortset fra det første afsnit, til en negativ kritik af den anmeldte bog. Især koncentrerer kritikken sig om kapitel 10, som i bogen repræsenterer fire sider, det vil sige 2,04 \% af det samlede sidetal. Kritikken omhandler beskrivelsen af sygehusenes funktionsmåder i den klassiske arabiske-islamiske civilisation, og forfatteren beskyldes for her at videreføre gamle klicheer og sejlivede myter om disse sygehuses modernitet i forhold til nugældende standard. Disse myter skulle ifølge Perho allerede have været tilbagevist i 1980erne af forfattere som Michael Dols, Gary Leiser, Vivian Nutton og Lawrence Conrad. Ser man på værker som Encyclopaedia of the History of Arabic Science (1996), Turner (1999) og Porman \& Savage-Smith (2007 ) viser det sig, at der ikke har dannet sig konsensus blandt forskerne om disse sager, således som Perho lader forstå, idet den historiske realitet af de af Perho benægtede forhold bekræftes i disse værker. Desuden er denne beskrivelse i Arabisk Medicin en beskrivelse af sygehusenes funktionsmåder i det 12. og 13. århundrede, hvilket klart fremgår af bogen, hvilket Perho ikke bemærker i sin kritik, således at det ser ud som om beskrivelsen af sygehusenes funktionsmåder gælder hele den middelalderlige islamiske verden som sådan. Perho skriver:

I sin beskrivelse af sygehuse definerer Philippe Provençal iwaner (høje nicher) som "store centrale haller" og tillægger bygningerne "specielle afdelinger for patienter med psykiske sygdomme, med febersygdomme, mavesygdomme eller øjensygdomme samt kirurgiske afdelinger". Der var også "afdelinger for sengeliggende patienter og rekonvalescerende patienter", "klinikker med fri uddeling af medicin for ambulante patienter" (p. 134-135). Med sit sprogbrug viderefører han en gammel kliché om, at de middelalderlige islamiske sygehuse til forveksling lignede vore store moderne sygehuse med specialiserede afdelinger.

Dette billede af modernitet forstærkes, når titlen $r a$ 'is al-atibba' forklares som "en embedslæge" (p. 136), og når forfatteren hævder at "en del af de offentlige statsudgifter ... gik til driften af sygehusene" (p. 135). Det vides ikke i dag, hvad titlen $r a$ 'is al-atibba' faktisk indebar. 
Her afslører Perho åbenbart en brist i hendes forståelse af det danske sprog. Jeg har ikke skrevet, at sygehusene havde medicinske specialafdelinger. Det ville have været en udpræget anakronisme, men at de havde specielle afdelinger, hvor ordet speciel her er synonymt med ordet særlig. Det mærkværdige i denne sammenhæng er, at Perho skriver det samme som jeg i sin Ph.d. afhandling fra 1995. Perho skriver f.eks. således:

[The Manūrī Hospital] was a large establishment containing wards for the treatment of different diseases. Men and women were cared for in separate sections. The sultan had established a foundation [waqf] that yielded one million dirhams per year for the running costs of the hospital. (Perho $1995 \mathrm{~s} .51$ $52)$.

Desuden skriver hun i samme afhandling, at ra 'is al-atibba' kontrollerede lægegerningen, dvs. at deres funktion var på linje med det vi kalder for en embedslæges. Perho skriver således:

Charlatans were a constant problem and some control measures were necessary.The supervising of the medical profession seems tohave been one of the duties of the chief physician ( $r \bar{a}$ 'is al-atibba') who was appointed by the sultan or the governor and was assicitated with the royal court

Vedrørende Perhos udsagn om:

De middelalderlige sygehuse i det islamiske imperium var udmærkede institutioner, men de var ikke sygehuse i vores forstand. De var private islamiske velgørenhedsinstitutioner, som fik deres midler fra stiftelser (waqf). Nogle sultaner etablerede sygehuse, men de gjorde det som private fromme mæcener, og sygehusene blev ikke finansieret af statskassen (bayt al-mal).

Både dette udsagn og det forrige fra Perhos anmeldelse af min bog bliver modsagt $\mathrm{i}$ en af de nyeste publikationer, hvorved det dokumenteres, at Perhos bestemte udsagn ikke kan støttes af en aktuel konsensus blandt forskerne (Porman \& Savage-Smith 2007 s. 97 og s. $100)$.

Angående min behandling af den profetiske medicin skriver Perho:

Philippe Provençal behandler profetens medicin meget kortfattet (s. 43-44) og affærdiger den som ikke-rationel og som en blanding af religion og sundhedslære (s. 43). Han referer kun til Manfred Ullmanns (1970) behandling af emnet, men nævner ingen nyere forskning, der mere nuanceret beskriver profe-

(C) Forfatteren og Tidsskrift for Islamforskning, ISSN 1901-9580, publiceret 15-02-2010 
tens medicin som teologers forsøg på at indarbejde islamiske normer i medicinsk teori og praksis.

At jeg kun har nævnt Ullmann (1970) i min behandling af den profetiske medicin er positivt forkert, da jeg også henviser til Savage-Smith (1996) endda to gange, mod Ullmann, som jeg kun henviser til en gang i denne passage (Provençal 2007 s. 43), idet jeg henviser til begge forfattere vedrørende en god indføring i profetisk medicin. Desuden bringer jeg i samme passage filosoffen og sociologen Ibn Khaldûns (1332-1406) refutation af den profetiske medicin, idet han betragter den som ikkerationel og ikke baseret på religiøse bud (Provençal 2007 s. 44). Denne refutation bliver ikke nævnt eller kommenteret.

I Savage-Smiths indføring bliver profetisk medicin beskrevet, i hvert fald for visse teksters vedkommende, som en alternativ medicin, som prøvede på at forene eller sammenføje den primitive arabiske medicin fra ørkentiden men de græske humorale medicinske teorier (Savage-Smith 1996).

At den profetiske medicin ikke var baseret på nogen sammenhængende medicinsk teoretisk basis, og at den satte et rent trospostulat, nemlig at profetens og koranens ord stod over den rationelle filosofi, som repræsenteredes af den græske filosofi, og som den klassiske arabiske-islamiske medicin var baseret på, og at den profetiske medicin derfor stod for en ikke rationel tankestrømning, er hævet over enhver tvivl jf. citat fra Ibn al-Qayyim hos Perho (1995) s.81:

The medicine of the Prophet is not like the medicine of the physicians. The prophet's medicine is sure, definite, and divine. It originates in revelation, light of prophecy, and perfect intellect.

På trods af dens fælles flade med medicin betyder det, at dens nærmere analyse rettelig hører hjemme under religionshistorie, og selv om det er fuldt ud legitimt at beskrive den i et værk om medicinens historie, er det lige så legitimt at omtale den kort og henvise den til en religionshistorisk redegørelse.

At den profetiske medicin prøvede på at kombinere den græske humorale medicin med den indfødte oprindelige arabiske, som ikke stod for nogen sammenhængende medicinsk opfattelse, gør den ikke rationel, men svarer til at visse udøvere af asiatiske medicinske traditioner i vore dage bruger rask væk betegnelser fra den vestlige medicin for at give deres praksis en større legitimitet, eller at moderne kreationister prøver på at anvende 
moderne naturvidenskabelige termer og forklaringer, for at agere "videnskabeligt". Det kan også ses af, at værkerne i profetisk medicin bruger særdeles enkle behandlingsformer og medikamenter, og desuden bruger adskillige bønner og fromme ord som led i sygdomsbehandlingen (Porman \& Savage-Smith 2007 s. 72). Derudover er trolddom, hekseri og ånder anerkendt som årsag til sygdomme i den profetiske medicin (Perho 1995 ss. 9091 og s. 145).

Hvis lægernes behandlinger var accepteret, og det var et problem for fromme teologer, at disse behandlingers teoretiske baggrund ikke var baseret på islamiske skrifter eller dogmer, og at de følgeligt prøvede på at legitimere behandlingerne ved at give dem en islamisk dogmatisk blåstempling ved hjælp af koran og sunna, fjerner ikke det faktum, at denne tankegang ikke var baseret på nogen sammenhængende medicinsk teoretisk basis (Porman \& Savage-Smith 2007 s. 74).

Perho synes at "En anden lille detalje er for en filolog den besynderlige påstand at moderne standard arabisk, som i dag bruges i de arabiske medier, er det samme klassiske arabiske, som Koranen blev skrevet på for mere end tusind år siden.” Jeg skrev:

Koranen blev nedfældet på dette højsprog, som derfor med nogle mindre forskelle, er lig med det klassiske arabiske sprog, som endnu i vore dage er det officielle sprog i de arabiske lande og lig med skriftsproget som sådan. Selv om de talte dialekter i de forskellige arabiske lande og regioner kan variere meget indbyrdes, således at forskellene kan minde om forskellene mellem de skandinaviske sprog, forbliver klassisk arabisk det skrevne sprog og også det talte sprog i radio og fjernsyn.

Jeg har ikke nævnt moderne standardarabisk i min fremstilling. At klassisk arabisk er det officielle sprog er velkendt, og at dette sprog i danner en fuld kontinuitet med det sprog som blev skrevet i den klassiske tid er også velkendt. At den moderne tid fordrer andre begreber end de man finder i de klassiske tekster eller koranen og at der er stilistiske forskelle er selvindlysende, men det moderne skriftsprogs identitet som klassisk arabisk er velattesteret (Fischer 2002 s. 1-2 ). Som officielt sprog er det også de talte mediers sprog, selv om det også er selvindlysende, at talesproget gør sig gældende i interviews og dramatik. Moderne standardarabisk er først og fremmest en sproglig benævnelse, som stammer fra vestlige arabister, og som betegner den sprognorm, som især findes i handelssproget og i journalistiske tekster, men det er klassisk arabisk, som er det officielle sprog og også den seriøse litteraturs sprog. F.eks. er Taha Husseins værker skrevet på

(C) Forfatteren og Tidsskrift for Islamforskning, ISSN 1901-9580, publiceret 15-02-2010 
klassisk arabisk og viser ikke de tendenser, som bliver fremstillet i en lærebog i moderne standardarabisk som Abu Chacra. Klassiske tekster bliver heller ikke oversat til "moderne standardarabisk".

Til slut undrer Perho sig over, at jeg selv oversætter korancitaterne i stedet for at bruge Wulffs oversættelse:

Til sidst vil jeg udtrykke vis undren over, at forfatteren har valgt selv at oversætte de korancitater, som han anvender, når han i stedet med fordel kunne have brugt Ellen Wulffs udmærkede danske oversættelse. Philippe Provençals oversættelser er præget af unødvendige arkaiseringer og uklare formuleringer som på s. 27: "Ingen tvang i Religionen! Retledelsen har tydeliggjort sig fra vildfarelsen, så at hvo afsværger afguderiet og tror på Gud, har grebet i det fasteste greb uden brud overhovedet, thi Gud er den Hørende og vidende" (Koranen 2.256).

Det samme vers i Ellen Wulffs oversættelse:

Der er ingen tvang i religionen. Den rette vej er blevet tydelig over for vildfarelsen. Den, der fornægter afguderne og tror på Gud, holder fast i det stærkeste håndtag uden revner. Gud hører alt og ved alt. (Koranen, oversat af Ellen Wulff, Forlaget Vandkunsten 2006.)

Man kan undre sig over, at dansk stilistik i oversættelser af korte korancitater er et så fundamentalt forhold, at de bør betragtes som væsentlige i en redegørelse af naturvidenskabernes historie. Uden at ville komme ind på en diskussion af min oversættelses kvaliteter eller mangler på samme, må det bemærkes, at det altid er en fordel, hvis forfatteren bruger sine egne oversættelser, da det borger for boniteten af den filologiske forståelse uanset stilistikken.

\section{Litteratur}

Abu-Chacra, F., 2007: Arabic, an essential grammar. Routledge, London and New York. Fischer, W. 2002: A Grammar of Classical Arabic, Yale University Press. New Haven and London.

Perho, I. 1995: The Prophet's Medicine, A Creation of the Muslin traditionalist Scholars, Studia Orientalia Nr. 74, Helsinki.

Porman, P. E. \& E. Savage-Smith, 2007: Medieval Islamic Medicine, Edinburgh University press, Edinburgh.

Provençal, P. 2007: Arabisk Medicin, Aarhus Universitets Forlag, Aarhus.

R. Rashed (ed.) 1996: Encyclopaedia of the History of Arabic Science, Routledge, London \& New York.

(C) Forfatteren og Tidsskrift for Islamforskning, ISSN 1901-9580, publiceret 15-02-2010 
Savage-Smith, E. 1996: "Medicine" i R. Rashed (ed.) Encyclopedia of the History of Arabic Science, Routledge, London \& New York, ss. 389-399.

Turner, H. R. 1999: Science in Medieval Islam, an illustrated introduction, University of Texas Press, Austin. 